\title{
Problem Gender dalam Perspektif Psikologi
}

\author{
Ibrahim Nur A $\mathbf{1}^{*}$ \\ 1*UIN Sunan Gunung Djati Bandung; nuribrahim502@gmail.com
}

*Penulis Koresponden

Artikel Dikirim: 7 Agustus 2020;

Artikel Diterima: 21 Oktober 2020;

Artikel Dipubikasikan: 16 Desember 2020.

\begin{abstract}
Abstrak: Gender adalah sifat, peran, perilaku maupun karakteristik yang dikonstruksi secara sosial maupun kultural untuk membedakan laki-laki dan perempuan. Adanya pembedaan peran gender dalam masyarakat patriarki cenderung menyebabkan lahirnya ketidakadilan gender, khususnya bagi kalangan perempuan. Dalam perkembangannya, solusi yang ditawarkan untuk mengatasi ketidakadilan gender yaitu melalui pendekatan struktural, sosial dan pendidikan. Studi dalam penelitian ini memfokuskan pada perspektif psikologi terhadap ketidakadilan gender. Meliputi, perbedaan gender dari sudut pandang psikologi, dan analisis terhadap manifestasi ketidakadilan gender menggunakan teori hierarki kebutuhan Abraham Maslow. Penelitian ini menggunakan metode library research. Hasil temuan dari penelitian ini, yaitu jenis kelamin tidak menjadi faktor yang signifikan dalam menentukan kapasitas kecerdasan seseorang. Kemudian hasil analisis dengan teori Maslow menunjukkan bahwa ketidakadilan gender dapat menjadi faktor penghambat akan pemenuhan kebutuhan aktualisasi diri manusia.
\end{abstract}

Kata Kunci: Gender; Psikologi

\begin{abstract}
Gender is the nature, role, behavior and characteristics that are constructed socially and culturally to differentiate men and women. The existence of gender role differences in a patriarchal society tends to cause gender injustice, especially for women. During its development, the solutions offered to overcome gender injustice are through structural, social and educational approaches. The study in this research focuses on a psychological perspective on gender injustice. Includes, gender differences from a psychological point of view, and analysis of the manifestations of gender injustice using Abraham Maslow's hierarchy of needs theory. This research uses library research method. The findings of this study indicate that gender is not a significant factor in determining a person's intellectual capacity. Then the results of the analysis with Maslow's theory show that gender injustice can be an inhibiting factor in fulfilling human self-actualization needs.
\end{abstract}

Keywords: Gender, Psychology

\section{Pendahuluan}

Dewasa ini persoalan mengenai gender mendapat perhatian yang cukup luas. Beberapa penelitian tentang gender umumnya dikaitkan dengan Pendidikan (Fitriyasni, 2018), agama (Asmaret, 2018), maupun pembangunan (Hasanah \& Ikhsan, 2020). Banyaknya kajian akademis mengenai isu gender ini menunjukkan bahwa ketidakadilan gender yang terjadi dalam masyarakat masih belum menemui titik final penyelesaiannya. Oleh sebab itu, diperlukan proses dialektis antara permasalahan di lapangan dengan teori-teori hasil penelitian yang disajikan.

Dilihat secara historis istilah gender muncul terutama untuk membedakan antara jenis kelamin dan peran gender. Para psikolog feminis, misalnya, menggunakan kata gender untuk menggambarkan aspek psikologis dan sosial dari tindakan dan peran sosial (Chrisler \& McCreary, 2010). Sedangkan 
definisi umum dari gender sendiri yaitu sifat, peran, perilaku maupun karakteristik yang dikonstruksi secara sosial maupun kultural untuk membedakan laki-laki dan perempuan.

Karena merupakan konstruksi sosial, definisi gender berbeda-beda tergantung dengan latar sosial, tempat dan waktu. Apa yang dianggap sebagai ciri khas laki-laki di suatu tempat, bisa jadi merupakan ciri khas perempuan di tempat lain. Apa yang menjadi ciri khas perempuan saat ini, bisa jadi hal yang tidak identik dengan perempuan pada masa mendatang.

Hal yang sebenarnya menjadi persoalan mengenai gender adalah ketika terjadi struktur ketidakadilan yang disebabkan oleh perbedaan peran gender yang berlaku di masyarakat tersebut. Dalih utama yang digunakan yaitu bahwa perbedaan biologis antara laki-laki dan perempuan menunjukkan adanya pembedaan terhadap hak-hak dan kesempatan bagi keduanya (Zubeir, 2012).

Menurut Mansour Fakih, setidaknya terdapat 5 manifetasi dari ketidakadilan gender: a. marginalisasi (peminggiran), b. burden (beban ganda), c. subordinasi (sekunderisasi), d. stereotipe (pelabelan negatif), dan e. kekerasan (Fakih, 2002). Problem mengenai ketidakadilan gender ini selalu muncul dalam berbagai masyarakat meskipun upaya penyelesaiannya diusahakan secara terusmenerus baik melalui pendekatan struktural (hukum dan kebijakan) (Instruksi Presiden No. 9, 2002), sosial, maupun pendidikan.

Dalam ranah akademis terdapat aneka pendekatan dalam mengkaji mengenai gender. Secara umum psikologi menjelaskan bagaimana norma-norma mengenai seksualitas dan gender membentuk pemikiran, perasaan dan perilaku individu. Sosiologi menjelaskan bagaimana seksualitas dan gender dikonstruksi dalam konteks sosial dan historis yang spesifik. Dan antropologi menjelaskan mengenai peran seksual dan gender dalam perkembangan masyarakat lintas budaya dan zaman (Bosson, Vandello, \& Buckner, 2018). Selain itu, disiplin ilmu lain juga dapat digunakan untuk meneliti gender dengan fokus kajian yang berbeda-beda.

Di sini peneliti mencoba untuk menganalisis problem ketidakadilan gender dalam sudut pandang psikologi. Tesis awal mengenai ketidakadilan gender yaitu perbedaan jenis kelamin menyebabkan perbedaan peran. Hal ini karena terdapat anggapan bahwa jenis kelamin menentukan potensi, kapasitas, maupun kemampuan. Untuk menemukan fakta dibalik asumsi tersebut, maka dalam penelitian ini (1) akan dibahas mengenai temuan-temuan di bidang psikologi menyangkut ada tidaknya perbedaan psikologis antara laki-laki dan perempuan. Selanjutnya, dengan melihat ketidakadilan gender sebagai fakta yang dialami, maka (2) akan diteliti mengenai dampak psikologis ketidakadilan gender dari perspektif teori kebutuhan Maslow. Sehingga dapat diketahui korelasi antara ketidakadilan gender terhadap pemenuhan kebutuhan psikologis manusia untuk tersu berkembang.

Penelitian ini menggunakan metode library research, yaitu dengan menelusuri berbagai literatur yang berkaitan dengan tema. Jenis penelitian ini adalah penelitian kualitatif yang dianalisis menggunakan metode deskriptif-analisis. 


\section{Pembahasan}

\subsection{Tinjauan Konsep Gender}

Konsep tentang gender dapat dipahami melalui beberapa komponen, antara lain: peran gender dan atribut gender (meliputi ekpresi gender, identitas gender dan orientasi seksual) (Duwy, Evy, \& Priyo, 2019). Peran gender umumnya dikonstruksi oleh lingkungan sosial dimana individu tersebut berada. Meskipun sebenarnya seorang individu memiliki pilihan untuk menentukan perannya masing-masing, akan tetapi hal tersebut sering menimbulkan kesangsian karena mencoba keluar dari kebiasaan sosial. Misal, dalam suatu lingkungan masyarakat, konvensi sosial yang berlaku yaitu tugas seorang istri mengurus rumah dan tugas seorang suami mencari uang. Apabila ada seorang suami yang memilih untuk mengurusi rumah dan istri yang mencari nafkah, sedangkan keduanya dalam keadaan sehat, maka hal tersebut dapat memicu stigmatisasi bahwa si suami adalah seorang pemalas dan tidak bertanggung jawab, dan istrinya menjadi korban atas ketidakbertanggungjawaban suami sehingga terpaksa bekerja.

Selanjutnya yaitu atribut gender, meliputi ekspresi gender, identitas gender dam orientasi seksual. Ekspresi gender menyangkut bagaimana seorang individu mengekspresikan dirinya dengan atribut gender tertentu yang berlaku dalam masyarakat, seperti cara berpakaian dan gestur tubuh. Identitas gender, merupakan penghayatan dan kesadaran individu sebagai laki-laki atau perempuan. Sedangkan orientasi seksual, merupakan ketertarikan seksual dan emosional terhadap jenis kelamin tertentu.

Antara peran gender dan atribut gender terdapat proses dialektis, dimana peran gender yang merupakan hasil pendefinisian eksternal, dihadapkan dengan atribut gender yang merupakan pendefinisian secara internal. Dalam beberapa masyarakat, identitas dan ekspresi gender menjadi faktor penting dalam menentukan peran gender. Misalnya, dalam masyarakat Bugis yang memiliki lima pembagian identitas gender yaitu laki-laki, perempuan, laki-laki feminin, perempuan maskulin dan bisu (gabungan antara laki-laki dan perempuan). Berdasarkan pembagian tersebut, maka menjadi sesuatu yang wajar apabila laki-laki feminin mengambil peran domestik dan perempuan maskulin mengambil peran publik (Nurohim, 2018), berbeda dengan kultur lain yang tidak memiliki konsep laki-laki feminin atau perempuan maskulin, sehingga semua laki-laki "harus" berperan publik dan semua perempuan "harus" berperan domestik.

\subsection{Perbedaan Laki-laki dan Perempuan dalam Perspektif Psikologi}

Sebagaimana telah disebutkan sebelumnya, pembedaan peran gender dalam masyarakat pada umumnya didasarkan atas adanya anggapan bahwa laki-laki dan perempuan memiliki perbedaan kapasitas dan kemampuan yang dimilikinya. Oleh sebab itu, studi awal dalam psikologi gender berusaha untuk mencari apakah perbedaan antar laki-laki dan perempuan sesuai dengan kenyataan atau hanya merupakan asumsi yang berkembang luas. Beberapa hasil penelitian tentang hal ini di antaranya:

1. Melhuish, dkk dalam penelitiannya menemukan bahwa jenis kelamin tidak memiliki pengaruh yang signifikan dalam hal kemampuan matematis. Perbedaan kemampuan tersebut lebih dipengaruhi oleh faktor lain, seperti keadaan sosial ekonomi, pendidikan yang efektif, lingkungan belajar di rumah dan tingkat pendidikan ibu (Bosson et al., 2018; Melhuish et al., 2008) . 
2. Matthias Mehl, dkk melakukan penelitian untuk membuktikan apakah benar perempuan lebih banyak bicara daripada laki-laki. Dari penelitian yang dilakukan, mereka menemukan bahwa tidak ada perbedaan antara laki-laki dan perempuan dalam jumlah kata yang diucapkan sehari-hari. Penelitian lain yang dilakukan oleh Leaper dan Smith menunjukkan bahwa terdapat perbedaan kecil antara laki-laki dan perempuan dalam hal banyaknya kata-kata yang diucapkan dan perbedaan tersebut bergantung pada usia. Anak perempuan di bawah usia 3 tahun lebih banyak bicara daripada anak laki-laki di usia yang sama (Bosson et al., 2018).

Hasil temuan di atas menunjukkan bahwa jenis kelamin tidak menjadi variabel yang signifikan terhadap kapasitas yang dimiliki seseorang. Terdapat variabel lain yang bersama-sama menentukan perbedaan kemampuan yang dimiliki antar individu. Adapun asumsi dan stereotip yang berkembang dalam masyarakat mengenai kualitas dan sifat laki-laki dan perempuan pada tahap tertentu berperan dalam proses identifikasi individu untuk lebih dekat dalam sifat tersebut.

\subsection{Teori Kebutuhan Maslow dan Problem Gender}

Ketidakadilan gender merupakan salah satu bentuk dehumanisasi, dapat dikatakan demikian karena hak-hak dan kesempatan yang seharusnya dimiliki oleh setiap individu menjadi tercerabut hanya karena alasan jenis kelamin. Dehumanisasi ini tidak hanya dialami oleh perempuan yang umumnya menjadi pihak tertindas, akan tetapi juga dialami oleh laki-laki karena melanggengkan ketidakadilan dan penindasan tersebut berlangsung (Bukido, 2016). Sebagai antitesis dari dehumanisme adalah humanisme. Jika dehumanisasi adalah tidak memanusiakan manusia, maka humanisme adalah upaya untuk memanusiakan manusia, untuk mengembalikan harkat martabat dan kesempatan untuk mengaktualisasikan potensi yang dimiliki setiap orang.

Dalam displin ilmu psikologi terdapat aliran ketiga yang muncul sebagai respon terhadap psikoanalisis (yang memandang manusia penuh dorongan negatif) dan behaviorisme yang memandang manusia dengan (secara mekanis). Aliran tersebut adalah psikologi humanistik yang memandang manusia secara positif serta sangat menekankan terhadap kesadaran dan aktualisasi diri. Beberapa tokoh dari aliran ini yaitu Abraham Maslow, Carl R. Roger, Arthur Combs, Aldous Huxley, David Mills dan Stanley Scher (Syifaâ, 2008).

Abraham Maslow adalah salah satu tokoh sentral dalam psikologi humanistik. Ia terkenal dengan penelitiannya atas motivasi-motivasi yang mendorong manusia untuk berkembang. Motivasi-motivasi ini kemudian diformulasi dalam bentuk teori kebutuhan yang hierarkis. Kebutuhan di tingkat yang paling dasar adalah kebutuhan fisiologis, dan kebutuhan di tingkat yang paling tinggi adalah kebutuhan aktualisasi diri. Kebutuhan-kebutuhan tersebut didefinisikan sebagai berikut (Ivancevich John, Robert, \& Matteson Michael, 2006):

1. Kebutuhan fisiologis, yaitu kebutuhan yang harus dipenuhi agar seseorang dapat melanjutkan keberlangsungan hidupnya. Kebutuhan ini adalah kebutuhan dasar biologis setiap orang, meliputi kebutuhan akan makanan, minuman, homeostasis, tempat tinggal, seks.

2. Kebutuhan akan keamanan dan keselamatan (safety and security) yaitu kebutuhan untuk bebas dari ancaman, bahaya dan bencana. Kebutuhan ini di antaranya mendorong seseorang untuk mencari tempat tinggal yang layak agar terhindar dari kejahatan maupun bencana alam; mendorong 
seseorang untuk mencari pekerjaan agar memiliki persiapan terhadap kemungkinankumungkinan buruk di masa depan; mendorong seseorang untuk selalu menjaga kesehatan; dan lain sebagainya.

3. Kebutuhan akan kebersamaan, sosial, dan cinta. Seperti dorongan untuk memiliki teman dan keluarga, afiliasi terhadap suatu kelompok atau komunitas, interaksi dan cinta. Kebutuhan ini penting utuk dipenuhi untuk menghindarkan diri dari rasa kesepian, terasing, dan depresi. Dengan berinteraksi serta menjalin hubungan, seseorang akan memiliki ruang untuk saling berbagi, belajar memahami, dan mengembangkan potensi.

4. Kebutuhan akan harga diri. Pada tahap ini, seseorang memiliki kebutuhan untuk diakui baik oleh dirinya sendiri maupun dari orang lain atas usaha-usaha yang telah dicapainya. Kebutuhan akan apresiasi ini penting karena mampu memunculkan rasa percaya diri dan motivasi yang lebih untuk terus berkembang.

5. Aktualisasi diri. Kebutuhan untuk mencapai titik paling tinggi dari segala potensi dan kemampuan yang dimiliki. Pada tahap ini seseorang akan melakukan usaha terbaik agar menjadi pribadi yang utuh.

Teori Maslow mengasumsikan bahwa orang berusaha memenuhi kebutuhan yang mendasar sebelum mengarahkan perilaku mereka pada pemenuhan kebutuhan di tingkat yang lebih tinggi, beberapa hal pokok dalam memahamai pemikiran Maslow tentang pendekatan hierarki kebutuhan antara lain,

1. Kebutuhan yang sudah terpuaskan akan berhenti memberikan motivasi. Misalnya, bagi seseorang yang telah memiliki rumah dengan jaminan keamanan dari pencurian atau bencana, ia tidak akan termotivasi lagi untuk mencari rumah lain dengan jaminan keamanan serupa, akan tetapi ia akan lebih termotivasi untuk mencapai tingkat kebutuhan yang lebih tinggi yaitu untuk mencari pasangan hidup, komunitas yang memiliki kesamaan hobi, dan lain sebagainya.

2. Kebutuhan yang tidak terpuaskan dapat menyebabkan rasa frustasi, konflik, dan stress. Orang yang selalu menemukan jalan buntu atas usahanya untuk memenuhi kebutuhan, cenderung menganggap bahwa ada yang sesuatu yang salah, baik dari dirinya sendiri atau orang lain. Hal ini memicu konflik dalam diri, rasa frustasi dan stres karena usaha yang dilakukan dirasa sia-sia dan tidak kunjung membuahkan hasil.

3. Maslow mengasumsikan bahwa setiap orang memiliki kebutuhan untuk tumbuh dan berkembang, dan sebagai akibatnya akan terus berusaha bergerak ke atas dalam hierarki untuk mencapai aktualisasi diri. Dengan kata lain, dorongan motivasi muncul untuk mencapai kebutuhankebutuhan yang belum terpenuhi. Sehingga seseorang akan terus bergerak ke tingkat kebutuhan yang lebih tinggi dan tidak berhenti pada satu tingkat tertentu.

Berdasarkan teori ini, maka dapat dipahami salah satu faktor yang menyebabkan para feminis sering menyuarakan persoalan ketidakadilan gender, yaitu karena terdapat hambatan-hambatan baik secara sosio-kultural maupun struktural dalam pemenuhan kebutuhan-kebutuhannya sebagai manusia.

Lebih lanjut jika melihat pada manifestasi ketidakadilan gender yang dikemukakan oleh Mansour Fakih dan dikaitkan dengan teori kebutuhan Maslow maka akan didapatkan hasil sebagai berikut. 
Pertama, kekerasan (violence) terhadap perempuan. Kekerasan terhadap perempuan merupakan salah satu topik penting yang perlu segera ditangani. Kekerasan dalam konteks ini bisa berwujud kekerasan fisik, seksual maupun psikologis. Komnas perempuan dalam Catatan Tahunan (CATAHU) 2019 mencatat bahwa terdapat 431.471 kasus kekerasan terhadap perempuan yang dilaporkan dan ditangani sepanjang tahun 2019, data ini menunjukkan adanya kedaikan sebesar 6\% dari tahun sebelumnya (406.178 kasus). Dari data lembaga mitra pengada layanan yang berjumlah 14.719 kasus, yang terjadi dalam ranah privat/personal tercatat sebesar 11.105 kasus, ranah publik/komunitas sebanyak 3.602 kasus dan ranah negara sebanyak 12 kasus.

Jenis dari kekerasan ini pun beraneka ragam, mulai dari kasus kekerasan dalam rumah tangga, dalam hubungan pacaran, pencabulan, perkosaan, pelecehan seksual, dan aksi cyber crime (ancaman dan intimidasi penyebaran foto dan video porno korban) (Komnas Perempuan, 2019). Data kekerasan terhadap perempuan ini merupakan bukti bahwa ketidakadilan gender yang terjadi dalam masyarakat masih sangat tinggi. Selain itu, masih terdapat kekerasan-kekerasan lain yang tidak dilaporkan dan belum terhitung jumlahnya.

Dari sudut pandang teori kebutuhan, kekerasan yang terjadi kepada perempuan merupakan salah satu bentuk penghilangan atas rasa aman yang merupakan tahapan kebutuhan kedua setelah pemenuhan kebutuhan fisiologis. Ketidakterpenuhinya rasa aman ini dapat menyebabkan seseorang mengalami gangguan psikologis, dalam beberapa kasus korban atas kekerasan tersebut akan mengalami depersi, post traumatic stress disorder (PTSD), maupun gangguan perilaku, kognisi dan emosional (Fu'ady, 2011).

Kedua, marginalisasi atau pemiskinan terhadap perempuan. Hal ini utamanya berkaitan dengan kebijakan baik itu di ranah domestik maupun publik yang meminggirkan posisi kaum perempuan. Banyak kasus di dunia korporasi modern di mana posisi-posisi penting dalam perusahaan sebisa mungkin tidak diberikan kepada perempuan lantaran "kodrat alamiah" perempuan dianggap mengganggu produktifitas kerja.

Di Indonesia sendiri marginalisasi terhadap perempuan dalam artian pembatasan terhadap hakhak untuk ikut terlibat dalam pembangunan dicoba untuk ditanggulangi dengan adanya beberapa regulasi yang dikeluarkan pemerintah. Misalnya saja Instruksi Presiden No. 9 Tahun 2002 Tentang Pengarusutamaan Gender dalam Pembangunan Nasional.

Akan tetapi problem marginalisasi terhadap perempuan seringkali bermanifestasi dalam bentuk lain. Di antaranya yaitu dalam karya literatur baik berupa novel, maupun buku teks sekolah. Meskipun tidak menyasar individu secara langsung, tapi pengaruh dari bacaan tersebut dapat mengkonstruk gambaran dan pemahaman seseorang tentang gender.

Ditinjau dari sudut pandang teori kebutuhan Maslow, problem marginalisasi ini muncul sebagai hambatan seseorang terhadap pemenuhan kebutuhan akan harga diri. Dalam beberapa hal, ini juga menghambat seseorang dalam proses aktualisasi diri karena adanya pembatasan terhadap hak partisipasi perempuan.

Ketiga, adanya subordinasi perempuan. Subordinasi perempuan diartikan sebagai 'penomorduaan' perempuan, bahwa perempuan lebih lemah atau rendah dari laki-laki, sehingga kedudukan, fungsi dan peran perempuan seakan-akan menjadi lebih rendah dibanding laki-laki (Wati 
\& Saifulloh, 2020). Subordinasi perempuan sangat berkaitan erat dengan konstruk sosial dan wacana yang berkembang dalam masyarakat. Dalam perkembangannya, subordinasi ini tidak hanya berkaitan dengan pembagian peran domestik yang secara khusus diberikan untuk perempuan, atau pembatasan terhadap pemberian posisi penting bagi perempuan, akan tetapi komodifikasi perempuan dalam ruang digital juga termasuk dalam subordinasi.

Ditinjau dari sudut pandang teori kebutuhan Maslow, adanya subordinasi perempuan dalam wilayah kerja merupakan salah satu bentuk hambatan dalam upaya pemenuhan kebutuhan fisiologis secara mandiri. Dapat dikatakan demikian karena kerja merupakan upaya untuk memperoleh modal ekonomi untuk keperluan sandang, pangan, papan.

Hal ini tentu tidak berlaku bagi perempuan yang didomestifikasi dengan jaminan kebutuhan fisiologis dari suami. Dalam hal ini kebutuhan yang dihambat oleh adanya domestifikasi adalah kebutuhan akan pertemanan dan interaksi sosial. Dalam derajat lain domestifikasi ini juga menghambat aktualisasi diri seorang perempuan yang mencita-citakan untuk berkarir.

Subordinasi jenis lain yaitu menjadikan perempuan sebagai komoditas seksual, baik dalam prostitusi konvensional, prostitusi online maupun konten pornografi. Salah satu bentuk komodifikasi perempuan yaitu dalam aplikasi whatsapp, dimana sering terdapat stiker gambar perempuan dengan muatan-muatan seksual yang digunakan sebagai bahan candaan. Dari sudut pandang teori Maslow, komodifikasi ini merupakan bentuk kurangya/tidak adanya penghargaan dari orang lain terhadap perempuan.

Keempat, adanya stereotip terhadap perempuan. Citra bahwa perempuan cenderung sensitif, irrasional, lemah dan tidak independen menyebabkan perempuan dalam banyak hal mengalami diskriminasi. Pencitraan negatif perempuan ini belakangan kian masif lantaran media massa juga kurang menunjukkan sensivitasnya terhadap kepentingan perempuan. Lihat misalnya iklan-iklan di televisi, di mana perempuan lebih banyak dicitrakan sebagai makhluk domestik, lemah dan tergantung pada laki-laki.

Stereotip terhadap perempuan berkaitan erat dengan konstrusi masyarakat tentang definisi personalitas perempuan dan atribut-atribut gender yang melekat padanya. Di antara stereotip ini misalnya bahwa perempuan dalam berbagai pengambilan keputusan lebih didasarkan atau dorongan emosional daripada kemampuan berfikir logis, oleh sebab itu perempuan dianggap tidak cocok untuk menjadi pemimpin.

Dari sudut pandang teori kebutuhan Maslow, stereotip-stereotip yang muncul dalam konteks sosial terhadap perempuan memiliki pengaruh yang lebih besar dalam menghambat perkembangan pemenuhan kebutuhan dalam tiap hierarki. Karena stereotip tersebut menyerang secara langsung terhadap kondisi psikologis seseorang dan mencegah berkembangnya dorongan motivasi untuk mencapai sesuatu.

Dalam psikologi behavior seseorang bertindak terutama karena adanya reward dan punishment. Jika dikaitkan dengan hal di atas, stereotip merupakan salah satu jenih punishment dalam kategori sosial meski dalam beberapa hal tidak ditemukan adanya rasionalitas dari hal tersebut. Meskipun stereotip ini menyerang secara psikologis, akan tetapi seseorang dengan motivasi yang lebih kuat tak akan terpengaruh dengan adanya stereotip tersebut. 
Kelima, beban ganda (double burden) yang harus ditanggung oleh perempuan. Domestifikasi perempuan telah menempatkan perempuan sebagai (seolah-olah) satu-satunya pihak yang berkewajiban mengurusi persoalan domestik (kerumahtanggaan). Beban ganda memang tidak dirasakan oleh perempuan yang tidak berkiprah di luar wilayah domestik. Hal ini berlaku bagi perempuan-perempuan yang berkarir di luar rumah (Fakih, 2008). Untuk memahami bagaimana tinjauan psikologis tentang double burden ini, maka terlebih dahulu harus diketahui faktor-faktor yang menyebabkan seorang perempuan memutuskan untuk mengambil beban ganda dengan bekerja.

1. Faktor Ekonomi

Ekonomi menjadi salah satu faktor utama yang mendorong perempuan untuk bekerja. hal ini berkaitan dengan kebutuhan-kebutuhan dasar fisiologis yang sifatnya jangka pendek yang menuntut seseorang untuk bersegera dalam memenuhinya. Dalam sebuah keluarga dimana seorang suami tidak dapat memenuhi kebutuhan primer dalam keluarga, mau tidak mau seorang istri harus ikut serta dalam bekerja untuk memenuhi kebutuhan ekonomi yang merupakan sarana untuk pemenuhan kebutuhan fisiologis.

2. Faktor Eksistensi diri

Dalam hierarki kebutuhan Maslow, eksistensi diri yang merupakan salah satu bentuk dari aktualisasi diri adalah kebutuhan tertinggi yang menuntut untuk dipenuhi setelah kebutuhankebutuhan dalam hierarki di bawahnya terpenuhi. Hal ini karena seseorang ingin mencapai kepenuhan diri dan kepuasan pribadi dalan hal pengerahan segala potensi yang dimilikiya.

3. Faktor sosial

Alasan atau faktor sosial yang mendorong perempuan untuk berkarir umumnya adalah keinginan untuk ikut serta dalam lingkungan yang aktif. Kebiasaan perempuan untuk selalu ingin berada di lingkungan kalangannya akan mampu membuatnya mengikuti apa yang dilakukan oleh kalangannya. Dalam teori Maslow hal ini masuk dalam upaya pemenuhan kebutuhan akan pertemanan dan interaksi sosial.

4. Faktor Budaya

Dalam hal ini terdapat konstruski sosial tentang peran gender perempuan untuk bekerja. Karena merupakan konstrusi sosial, sedikit banyak faktor ini menyebabkan seseorang untuk bekerja dengan keterpaksaan.

\section{Kesimpulan}

Studi psikologi tentang gender mengemukakan bahwa tidak ada perbedaan secara signifikan antar laki-laki dan perempuan dalam hal kemampuan matematis, dan banyak sedikitnya ucapan. Dengan kata lain, terdapat variabel lain yang lebih berpengaruh daripada jenis kelamin yang menentukan kemampuan intelegensi dan kemampuan komunikasi, yaitu seperti pendidikan, lingkungan dalam rumah, bacaan dan lain sebagainya. Oleh sebab itu, pembedaan hak antara laki-laki dan perempuan dengan alasan laki-laki pintar (karena ia laki-laki) tidak dapat dibenarkan.

Selanjutnya, berdasarkan tinjauan teori kebutuhan Maslow dalam membaca lima manifestasi ketidakadilan gender (kekerasan, subordinasi, marginalisasi, stereotype, dan beban ganda) ditemukan 
bahwa adanya ketidakadilan gender menjadi hambatan dalam pemenuhan kebutuhan manusia yang hierarkis, sehingga dapat memicu munculnya konflik, frustrasi maupun stres.

\section{Referensi}

Asmaret, D. (2018). KAJIAN TENTANG GENDER PERSPEKTIF ISLAM (Studi Analisis Tentang Posisi Perempuan dan Laki-laki dalam Islam). JURIS (Jurnal Ilmiah Syariah). https://doi.org/10.31958/juris.v17i2.1164

Bosson, J. K., Vandello, J. A., \& Buckner, C. E. (2018). The psychology of sex and gender. SAGE Publications.

Bukido, R. (2016). DIKOTOMI GENDER (Sebuah Tinjauan Sosiologis). Jurnal Ilmiah Al-Syir'ah. https://doi.org/10.30984/as.v4i2.205

Chrisler, J. C. [Ed], \& McCreary, D. R. [Ed]. (2010). Handbook of gender research in psychology, Vol 1: Gender research in general and experimental psychology. In Handbook of gender research in psychology, Vol 1: Gender research in general and experimental psychology.

Duwy, S., Evy, N., \& Priyo, S. (2019). Konstruksi Makna Ketidakadilan Berbasis Gender Menurut Sudut Pandang Aktivis Women'S March Bandung (Studi Fenomenologi). Journal.Uin-Alauddin.Ac.Id.

Fakih, M. (2002). Analisis Gender dan Transformasi Islam. Yogyakarta: Pustaka Pelajar.

Fakih, M. (2008). Analisis Gender dan Transformasi Sosial (Cetakan VI). Yogyakarta: Pustaka Pelajar.

Fitriyasni, M. S. (2018). PENDIDIKAN BERBASIS ADIL GENDER (Solusi dan Pemecahannya). FITRA, 2(2).

Fu'ady, M. A. (2011). DINAMIKA PSIKOLOGIS KEKERASAN SEKSUAL: SEBUAH STUDI FENOMENOLOGI. Psikoislamika : Jurnal Psikologi Dan Psikologi Islam. https://doi.org/10.18860/psi.v0i0.1553

Hasanah, U., \& Ikhsan, I. (2020). PEMBANGUNAN MANUSIA, KETIMPANGAN GENDER DAN PERTUMBUHAN EKONOMI DI INDONESIA. Jurnal Ilmiah Mahasiswa Ekonomi Pembangunan, 5(1), 46-53.

Instruksi Presiden No. 9. Pengarusutamaan Gender dalam Pembangunan Nasional. , (2002).

Ivancevich John, M., Robert, K., \& Matteson Michael, T. (2006). Perilaku dan Manajemen Organisasi. Erlangga, Jakarta.

Komnas Perempuan. (2019). Lembar Fakta dan Temuan Kunci Catatan Tahunan Komnas Perempuan. Retrieved from https://komnasperempuan.go.id

Melhuish, E. C., Sylva, K., Sammons, P., Siraj-Blatchford, I., Taggart, B., Phan, M., \& Malin, A. (2008). Preschool influences on mathematics achievement. Science, 321(5893), 1161-1162.

Nurohim, S. (2018). IDENTITAS DAN PERAN GENDER PADA MASYARAKAT SUKU BUGIS. SOSIETAS. https://doi.org/10.17509/sosietas.v8i1.12499

Syifaâ, R. (2008). Psikologi humanistik dan aplikasinya dalam pendidikan. EL TARBAWI, 1(1), 99-114.

Wati, L., \& Saifulloh, M. (2020). Subordinat Perempuan Dalam Aplikasi Percakapan Grup Whatsapp (Studi Kasus Penggunaan Sticker Sensual Di Grup Whatsapp). LUGAS Jurnal Komunikasi.

Zubeir, R. (2012). Gender Dalam Perspektif Islam. An Nisa'a, 7(2), 119-133. 